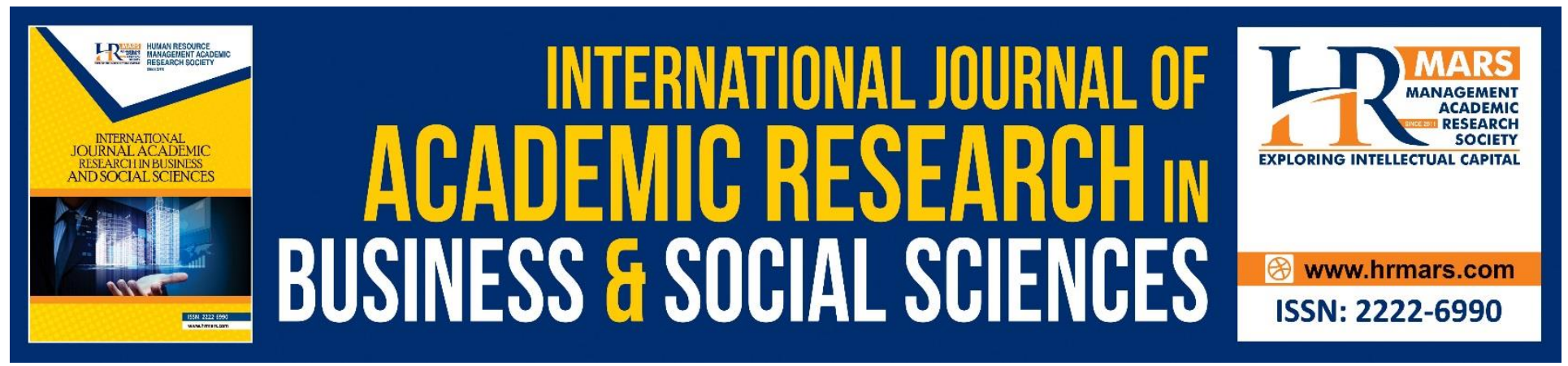

\title{
Wall Attack in Padlet in Enhancing Vocabulary Acquisition
}

\author{
Atiqah Ab Hamid, Liyana Nabilah Rosli \& Melor Md. Yunus
}

To Link this Article: http://dx.doi.org/10.6007/IJARBSS/v9-i1/5458

DOI: $\quad 10.6007 /$ IJARBSS/v9-i1/5458

Received: 23 Dec 2018, Revised: 26 Jan 2019, Accepted: 03 Feb 2019

Published Online: 08 Feb 2019

In-Text Citation: (Hamid, Rosli, \& Yunus, 2019)

To Cite this Article: Hamid, A. A., Rosli, L. N., \& Yunus, M. M. (2019). Wall Attack in Padlet in Enhancing Vocabulary Acquisition. International Journal of Academic Research in Business and Social Sciences, 9(1), 563-572.

\section{Copyright: (C) 2019 The Author(s)}

Published by Human Resource Management Academic Research Society (www.hrmars.com)

This article is published under the Creative Commons Attribution (CC BY 4.0) license. Anyone may reproduce, distribute, translate and create derivative works of this article (for both commercial and non-commercial purposes), subject to full attribution to the original publication and authors. The full terms of this license may be seen

at: http://creativecommons.org/licences/by/4.0/legalcode

Vol. 9, No. 1, 2019, Pg. 563 - 572

http://hrmars.com/index.php/pages/detail/IJARBSS

JOURNAL HOMEPAGE

Full Terms \& Conditions of access and use can be found at http://hrmars.com/index.php/pages/detail/publication-ethics 


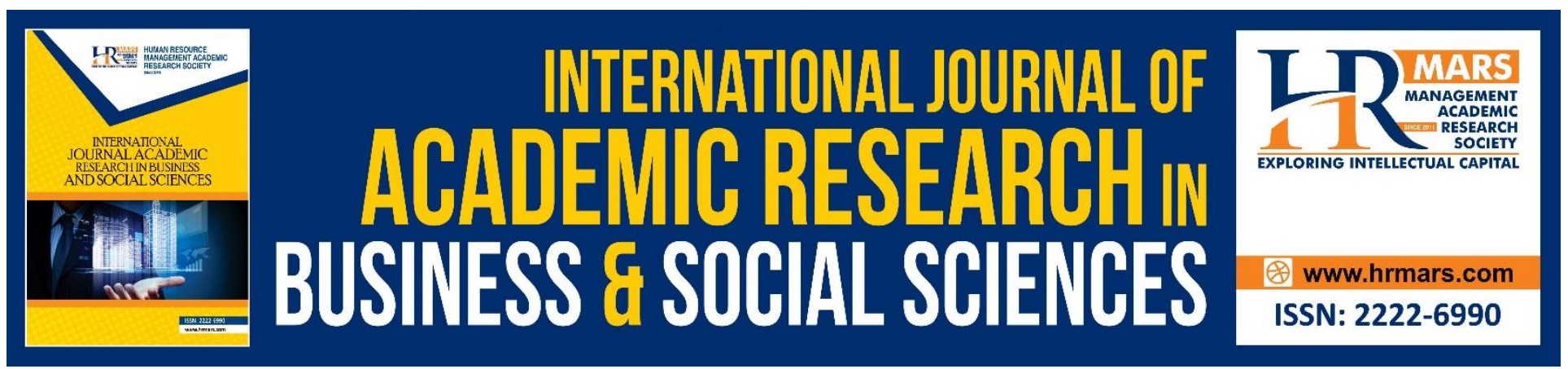

\title{
Wall Attack in Padlet in Enhancing Vocabulary Acquisition
}

\author{
Atiqah Ab Hamid ${ }^{1}$, Liyana Nabilah Rosli² \& Melor Md. Yunus ${ }^{3}$ \\ Faculty of Education, Universiti Kebangsaan Malaysia, Bangi, Selangor, Malaysia ${ }^{123}$ \\ atiqah_nohara@yahoo.com¹ liyananabilahrosli@gmail.com² melor@ukm.edu.my ${ }^{3}$
}

\section{Abstract}

Vocabulary acquisition is very crucial for Malaysian second language learners. However, the second language learner especially primary school pupils are having a problem in acquiring vocabulary. This study intends to explore the prospective outcome of using Wall Attack in Padlet, an online application in English as Second Language (ESL) classroom to improve vocabulary acquisition and develop pupils' motivation towards vocabulary learning. Action research was carried out to investigate the effectiveness of using Wall Attack in Padlet in improving pupils' vocabulary in English language and to discover pupils' motivation towards learning vocabulary. Thirty 10 -year-old primary school pupils from Mersing, Johor, Malaysia were chosen as the participants in this study. The data was collected by the means of pre- and post-tests and questionnaire survey. The data was later analysed using both descriptive and inferential analysis. The result from pre- and post- tests indicated a significant improvement in pupils' vocabulary acquisition. The result from the questionnaire survey also showed pupils positive motivation towards using Wall Attack in Padlet as a mean for learning vocabulary. The findings proved that the use of Wall Attack in Padlet is effective in enhancing pupils' performance in language learning, especially in English as a second language (ESL) learning context. Keywords: Padlet, Vocabulary, Effectiveness, motivate, English as Second Language

\section{Introduction}

It is not an easy task to implement English in Primary ESL classroom. The needs to cater to the pupils' individual differences, learning styles, various background, multiple intelligence and also different mother tongues and cultures are yet challenging. It is essential for educators to improve their skills as well as teaching methods and techniques in order to match the pupils' preferences. A study by Griggs and Dunn (1984), Smith and Renzulli (1982) and Wallace and Oxford (1992) pointed that suitable teachers' teaching style and learners' preferred learning style aid to increase learners' inspiration and motivation in learning. However, if there is any disparity between both styles, it affects students in becoming bored, loss of interest, discouraged, becoming inattentive and 
performing rather poorly in tests and assessments (Felder \& Henriques, 1995; Godleski, 1984; Oxford et al, 1991).

We are living in the decade of multimedia and the millennium of the Internet and the World Wide Web (www) (Yunus et al, 2009). Many children now start school technologically literate. They are used to the keyboard, tablet, smartphones, and any other technologies. Educators have to ask what effect does this interactivity have on teaching and learning. There is no doubt that innovation draws in pupils but the idea of what they learn and how they learn still relies upon the abilities of the teacher. By integrating information and communication technologies (ICT) into education, teachers and students are enlivened (Chua \& Yunus, 2012). Pupils are exposed to a variety of methods in learning, this especially boosts pupils' motivation besides being able to develop their problem-solving capabilities and to think critically. Furthermore, teachers could use technology to aid in teaching complicated concepts which are difficult for students to visualize thus increasing the quality of education (Chua \& Yunus, 2012).

Pedagogy in the $21^{\text {st }}$ century has to put an emphasis on the $4 \mathrm{Cs}$ - collaboration, critical thinking, creativity and communication (Bruniges, 2012). Teachers are encouraged to involve more in collaborative projects and gain insight through an international platform where educators across the globe are given the chance to share effective teaching approaches. In our fast-changing world, more of the same knowledge and skills will not be able to cope or address the challenges of the future. With the avalanche of information available online, the teacher is now more the facilitator of learning than the holder of all knowledge (Bruniges, 2012). The challenge as an educator is to ensure quality pedagogy works within the world of contemporary students and to keep upskilling to meet these needs. Meanwhile, the second language learner especially primary school pupils are having the problem with vocabulary acquisition.

As a result of the emergence and democratisation of pupils learning the components in English especially vocabulary as what has been proposed by the researchers, the possibility of teachers and students having to relearn how to vary the teaching and learning style has been opened up and has resulted in the necessity to acquire new literacy in the use and construction of digital resources (Ohler, 2009). Effectively, a new dimension in the relationship between the learner and the use of digital resources such as Wall Attack in Padlet is actually designated as a new learning tool to help the students in acquiring vocabulary. Owing to this matter, it is suggested to use new tool of teaching as to give new insights to the students to acquire new knowledge (Malcom, 2009) and to which the teacher can help the students in learning vocabulary. Thus, the aims of this study were to identify the effectiveness of using Wall Attack in Padlet in enhancing vocabulary acquisition as well as to motivate pupils to use it to improve their vocabulary.

\section{ICT in Malaysian Education Context}

According to Nordin (2013), the education system in Malaysia is mostly outdated in comparison to current global changes in a manner that outmoded pedagogical practices have been used to educate students in school. As such, Malaysia's Ministry of Education (MOE) feels the urgent need to re-evaluate the national education system as a whole resulting in the formulation of the Malaysia Education Blueprint 2013-2025. This remedy is to address the current increasing international education standard, national aspiration and society's expectation to equip students 
with skills that can accommodate the necessities of the $21^{\text {st }}$ century (Mustapa et al, 2016; Isaak, 2017). Therefore, it is a crucial key point for Malaysia's MOE to upgrade teacher's capacity to realize the $21^{\text {st }}$ century education as envisioned by the Malaysia Education Blueprint 2013-2025. Information and Communication Technology, then, is what supports and enables this kind of education progress in the $21^{\text {st }}$ century as its cutting edge and systematic instrument could cultivate a more favourable learning process (Yunus \& Suliman, 2014). The use of digital resources in the education system also received attention in the era of information and communication technology (ICT). Schools have been provided with physical facilities such as computer laboratory that is complete with hardware (computer, laptop, LCD projector, and internet) for the purposes of teaching and learning as an initiative through the Education Development Master Plan (PIPP) 2006 - 2010. In line with the move, administrators, teachers, and students are also exposed to a variety of knowledge and skills based on technology from time to time.

Wall Attack in Padlet

Technology has become a part of teaching tools as well as a support for learning. By implementing technological tools and application in language learning, it might be a good approach to scaffold learning and assist the pupils to acquire the target language. Thus, one of the technological tools that can be used is Padlet, an online application which looks like a virtual bulletin board and it is a powerful tool to support language learning. According to research done by (Haris et al, 2017), Padlet is effective in enhancing students' performance in language learning particularly in English grammar. The purpose of the study was to investigate the effectiveness of using Padlet in improving students' learning in English grammar. This experimental research was done at Universiti Sains Islam Malaysia (USIM) with thirty first-year undergraduate students. The findings of this study suggested that there was a significant improvement in students' performance when integrating Padlet in their grammar learning. Hence, Padlet has been proven to benefit the students in language acquisition.

\section{Vocabulary}

Vocabulary is important in second language learning. Sufficient knowledge of vocabulary makes learners able to understand others or express their own feelings. Recent developments in second and foreign language acquisition emphasize that non-native speakers require a solid foundation of vocabulary knowledge to become successful users of English in any academic achievement (Viera, 2016). For a second language learner especially in primary English as Second Language (ESL) classroom, acquiring vocabulary might be one of the concerns the pupils faced. Hence, in order to improve this situation, the use of teaching strategies might be helpful. One of the most widely implemented teaching and learning strategies nowadays is by integrating technology. A research done by Ko and Goranson (2014) investigated the effectiveness of an online technologyassisted vocabulary learning program used by Korean university students in Seoul, Korea. The results proved that about $95 \%$ of the university students who experienced Praxis Education technologyassisted vocabulary learning program believed that the program contributed greater impact on them. The participants were motivated to learn vocabulary by using this technologically based program as it was effective. 
INTERNATIONAL JOURNAL OF ACADEMIC RESEARCH IN BUSINESS AND SOCIAL SCIENCES

Vol. 9, No. 1, Jan, 2019, E-ISSN: 2222-6990 @ 2019 HRMARS

\section{Material and Methods}

\section{Study Design}

This study used action research design which based on Kemmis and McTaggart Action Research Model. The model was a spiral model comprising: (a) planning, (b) acting and observing, (c) reflecting and (d) re-planning (Kemmis \& McTaggart, 1990) as cited in (Brown, 2002). In the first step, the researchers identified the issue of vocabulary acquisition and develop a plan of action to solve the issue which was using Wall Attack in Padlet. Then, the researchers implemented the planned action towards the participants and observed the effects of the action for data collection. The third step was where the researchers reflected on the plan, action, and observations that had been done. For the last step, the plan had not been revised by the researchers as there was a significant improvement after the data had been analysed.

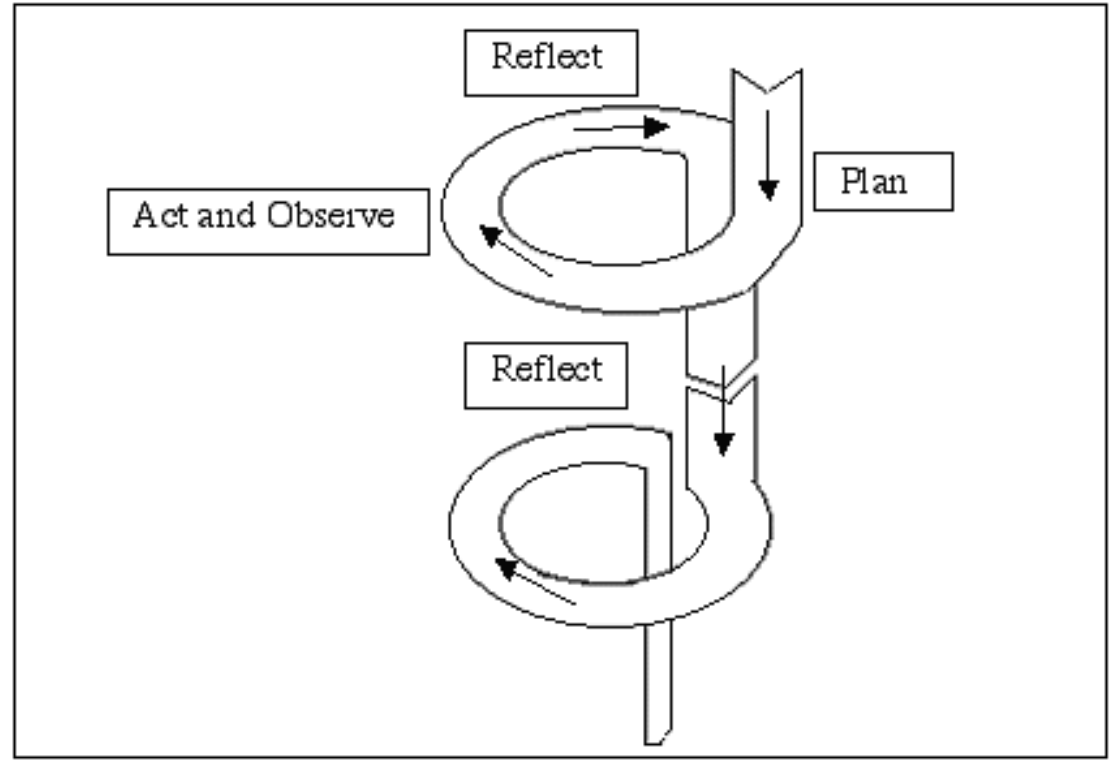

Figure 1. Kemmis and McTaggart action research model

\section{Participants}

The selected participants for this study were thirty 10-year-old primary school pupils from Mersing, Johor, the southern part of Malaysia. The selection of the participants was done based on simple random sampling. According to Taherdoost (2016), a simple random sample suggests that there is an equal probability of inclusion in a sample for every case of the population. All of them were learning English as their second language since they are the native speakers of Bahasa Melayu. They also had a wide range of English proficiency level which most of them were at the low and intermediate level and they only used English during English lesson in the classroom.

\section{Instruments}

One of the instruments used in this study was pre- and post- tests. The basic principle behind the pre- and post- tests design requires obtaining a pre-test measure of the outcome of interest before implementing the treatment and followed by a post-test on the same measure after treatment takes place (Salkind, 2010). The pre-test consisted of 15 items was given to the participants before they were introduced to Wall Attack in Padlet in order to evaluate their current vocabulary 
level. Then, the participants were given the post-test after two weeks of learning vocabulary using Wall Attack in Padlet. The items used in both pre- and post-tests were the same except the arrangement of the items was manipulated. Another instrument used was a questionnaire survey. The questionnaire items were provided with Yes/No statements and consisted of five items. The participants were asked to give a response to the questionnaire by ticking Yes or No. The researchers guided the participants if they did not understand any of the items included in the survey.

\section{Procedures}

The participants were given a pre-test in the form of worksheet before they started their lesson for topic "Good Values" in the first week. The pre-test served the purpose as a diagnostic tool to check their vocabulary knowledge. After the pre-test was carried out, the participants were taught about vocabulary which consisted of twenty words using Wall Attack in Padlet. The learning process took about two weeks and all the lessons and activities were implemented via Padlet. On the fourth week, the participants sat for post-test to evaluate their performance. At the end of the post-test, the participants had to complete a questionnaire survey.

\section{Data Analysis}

The data collected were analysed through descriptive and inferential statistics. Descriptive statistic method used to analyze the pre- and post- tests data were frequency and mean whereas the inferential statistic method applied was paired sample t-test as a mean to answer the research question. On the other hand, the data from the questionnaire survey was analysed using descriptive statistic method which was through percentage.

\section{Results}

The findings of this study would be discussed based on two research questions. The first question was to prove the effectiveness of using Wall Attack in Padlet in enhancing vocabulary acquisition in the English language. The data which was the scores of the participants in both preand post- tests were recorded and analysed through descriptive analysis in terms of frequency and mean; and inferential analysis by using paired sample t-test through Statistical Package for the Social Sciences (SPSS) software. Table 1 showed the comparison between these two tests in terms of frequency, mean, standard deviation and significant value.

Table 1. Results of pre- and post-test scores of the participants.

\begin{tabular}{|c|c|c|c|c|}
\hline Test & N & Mean & Standard Deviation & Significant Value \\
\hline Pre-Test & 30 & 6.967 & 3.167 & 0.000 \\
\hline Post-Test & 30 & 10.233 & 3.711 & \\
\hline
\end{tabular}

From the results, it proved that participants' vocabulary acquisition significantly increase from the pre- to post test. It specified a significant difference between the mean scores before and after using Wall Attack in Padlet in vocabulary acquisition ( $p>0.05)$. These mean scores projected a significant increment in participants' score after utilizing Wall Attack in Padlet. This analysis can be also proven by the score performance level as designated in Figure 2 below: 
INTERNATIONAL JOURNAL OF ACADEMIC RESEARCH IN BUSINESS AND SOCIAL SCIENCES Vol. 9, No. 1, Jan, 2019, E-ISSN: 2222-6990 @ 2019 HRMARS

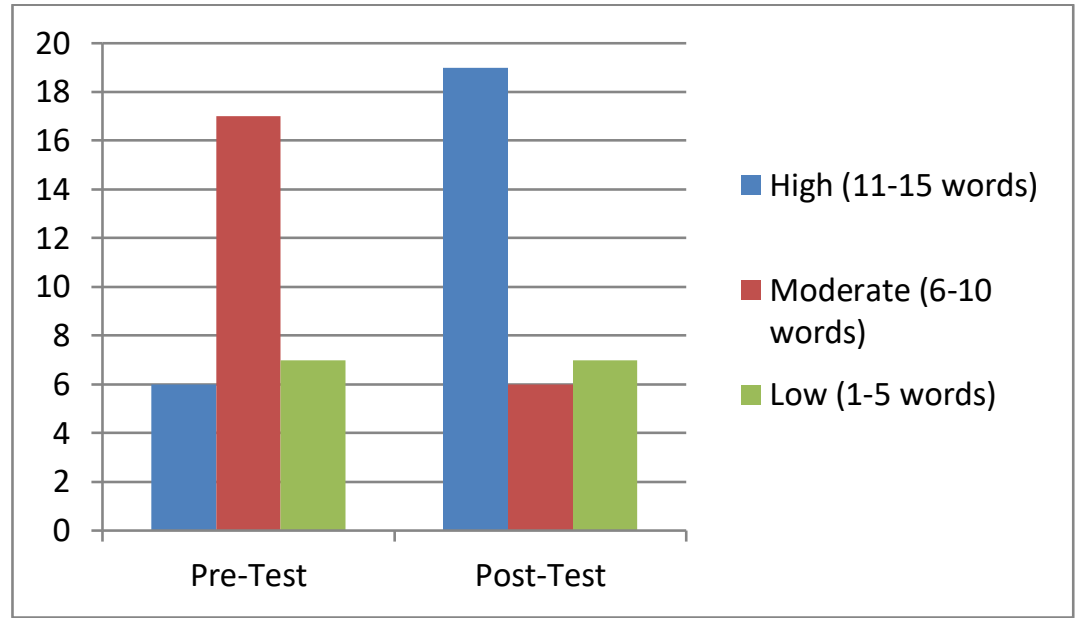

Figure 2. Pre- and Post-tests score performance

Based on the result, out of 30, 19 participants scored high level of vocabulary which was able to write eleven to fifteen words in their post-test compared to their pre-test. This number makes about 63\% percentages of students who performed better after incorporating Wall Attack in Padlet in their vocabulary learning. On the other hand, $20 \%$ obtained moderate level as they could write six to ten words for the post-test and $17 \%$ scored one to five words in their post- test. With the score performance level, there is a significant improvement illustrated to show the effectiveness of using Wall Attack in Padlet in enhancing students' vocabulary acquisition.

Overall, the differences in scores show that the use of Wall Attack in Padlet is effective yet helpful enough in improving participants' performance in vocabulary learning. This finding is parallel with other previous studies which showed the effective usage of Padlet in learning (Dembo \& Bellow, 2013; Fuchs, 2014; Ellis, 2015).

The second research question was to answer whether Wall Attack in Padlet can motivate pupils to use it to improve their vocabulary. The questionnaire items have been analysed and the data was calculated in percentages. The result can be referred in Table 2 below:

Table 3. Participants' motivation towards using Wall Attack in Padlet

\begin{tabular}{|c|l|c|c|}
\hline \multirow{2}{*}{$\begin{array}{c}\text { No } \\
\text { nny }\end{array}$} & \multicolumn{1}{|c|}{ Questionnaire Items } & \multicolumn{2}{|c|}{$\begin{array}{c}\text { Percentage of } \\
\text { Participants' Answers }\end{array}$} \\
\cline { 3 - 4 } & \multicolumn{1}{|c|}{ Yes } & No \\
\hline 1. & I like to learn new vocabulary using Wall Attack in Padlet. & $100 \%$ & $0 \%$ \\
\hline 2. & I find it interesting to learn vocabulary using Wall Attack in Padlet. & $100 \%$ & $0 \%$ \\
\hline 3. & $\begin{array}{l}\text { I understand the meaning of the words after I learned it through } \\
\text { Wall Attack in Padlet. }\end{array}$ & $83.3 \%$ & $16.7 \%$ \\
\hline 4. & $\begin{array}{l}\text { I feel confident to learn new vocabulary after I learned it through } \\
\text { Wall Attack in Padlet. }\end{array}$ & $66.7 \%$ & $33.3 \%$ \\
\hline 5. & $\begin{array}{l}\text { I feel satisfied when I understand new vocabulary through Wall } \\
\text { Attack in Padlet. }\end{array}$ & $80 \%$ & $20 \%$ \\
\hline
\end{tabular}


The findings in Table 2 indicated that the majority of participants were motivated to learn vocabulary by using Wall Attack in Padlet. Most of the items received a higher percentage which is above $80 \%$. Looking closely in terms of attitude on using Wall Attack in Padlet in vocabulary learning, Table 2 showed that in general, more than $50 \%$ of participants have positive attitudes towards Wall Attack in Padlet. 100 \% liked to learn new vocabulary using this tool as well as agreed that learning language via Wall Attack in Padlet was an interesting idea. 66.7\% agreed that Wall Attack in Padlet boosted up their confidence level in learning new vocabulary. However, there was a small number which was $16.7 \%$ that had been recorded as a group who still did not really get the meaning of the words even after they learned it through Wall Attack in Padlet. This can be explained as it was the first time for them to use Wall Attack in Padlet. Thus, even though they liked it, it still took a lot of time for them to get to know the tool and communicating using it for learning vocabulary. In terms of their satisfaction, $80 \%$ agreed that they feel satisfied when they understood the new vocabulary. Wall Attack in Padlet helped them to become active in language activity. Generally, most participants regarded Wall Attack in Padlet as an effective mean for learning the language and they are excited to use it in their language learning in the future.

\section{Discussion}

From the analyses of pre- and post-tests and questionnaire survey, it tends to be inferred that there was a significant increment in participants' performance when integrating Wall Attack in Padlet in enhancing their vocabulary acquisition. Likewise, the research participants supported the use of Wall Attack in Padlet and thought that it was motivating for them to learn vocabulary by using it. In contrary, there were also some participants who viewed their involvement in language learning activity by using Wall Attack in Padlet was obscure due to the fact that it was their first time to be introduced to this tool and what more to learn the language by using it. This ought to be an aspect to be considered by the researchers. Owing to that matter, it is believed that digital competency issue, as well as the technical side of the tool, can interrupt the learning process simply because the participants might take some time to get familiarized in using this tool before they can actually utilising it in their learning (Redecker et al, 2009).

\section{Conclusion and Implications}

In general, there is a significant improvement which has been justified from the findings. The differences obtained from the test results show that the use of Wall Attack in Padlet is effective yet helpful enough in improving participants' performance in vocabulary learning. In addition, majority of participants were motivated to learn vocabulary by using Wall Attack in Padlet and most of the items received a higher percentage which is above $80 \%$. The findings of the present and the previous studies also managed to support the effectiveness of Padlet in learning. Accordingly, Padlet is one of the technology advances that ought to be promoted and utilised as a tool to enhance the participants' vocabulary acquisition. As stated by Yamat et al (2014), language learning develops along with the teaching and learning process which requires teachers to keep updated to the current trend in language teaching. Wall Attack in Padlet is served as a medium for participants to effectively take part in their vocabulary learning. Participants' engagement in learning could also be set up through collaboration and sharing ideas by using this tool. This will undeniably assist them to be attentive of 
INTERNATIONAL JOURNAL OF ACADEMIC RESEARCH IN BUSINESS AND SOCIAL SCIENCES

Vol. 9, No. 1, Jan, 2019, E-ISSN: 2222-6990 (C) 2019 HRMARS

their own learning and thus improve their performance in learning the language. For future recommendation, further studies can be done on Padlet to a wider degree of other language skills for instance grammar, speaking and writing as there is limited research on using this tool in language learning. Hence, more research should be done to see the effectiveness of using Padlet in various contexts.

\section{Acknowledgement}

The authors gratefully acknowledge the research participants for taking part in this research.

\section{Corresponding Author}

Dr. Melor Md Yunus

Universiti Kebangsaan Malaysia

\section{References}

Brown, B. L. (2002). Improving teaching practices through action research (Doctoral dissertation). Virginia Polytechnic Institute and State University. Retrieved from http://hdl.handle.net/10919/26869

Bruniges, M. (2012). 21 $1^{\text {st }}$ Century Skills for Australian Students. NSW Department of Education \& Communities. Retrieved from https://jannali-

p.schools.nsw.gov.au/.../21st_century_skillsforaustralianstudents.pdf

Chua, P. L., \& Yunus, M. M. (2012). ESL teacher and ICT: Teachers' perception. Advances in

Language and Literary Studies, 3(1), 119-128. DOI: 10.7575/aiac.alls.v.3n.1p.119

Dembo, S., \& Bellow, A. (2013).Untangling the Web: 20 Tools to Power up Your Teaching. California, United States: Corwin Press.

Ellis, D. (2015, October). Using Padlet to Increase Engagement in Lectures. European Conference on elearning conducted at Hatfield, UK.

Felder, R. M., \& Henriques, E. R. (1995). Learning and teaching styles in foreign and second language education. Foreign Language Annals, 28(1), 21-31. DOI: 10.1111/j.1944-

9720.1995.tb00767.x

Fuchs, B. (2014). The writing is on the wall: Using Padlet for whole-class engagement. LOEX Quarterly, 40(4), 7- 9. Retrieved from https://uknowledge.uky.edu/cgi/viewcontent.cgi?article=1241\&context=libraries_facpub

Goldleski, E. S. (1984). Learning style compatibility of engineering students and faculty. Proceedings, Annual Frontiers in Education Conference ASEE/TEEE, Philadelphia, 362.

Griggs, S. A., \& Dunn, R. S. (1984). Selected case studies of the learning style preferences of gifted students. Gifted Child Quarterly, 28(3), 115-119. DOI: 10.1177/001698628402800304

Haris, M., Yunus, M. M., \& Badusah, J. (2017). The effectiveness of using padlet in esl classroom. International Journal of Advanced Research, 5(2), 783-788. DOI: 10.21474/IJAR01/3214

Isaak, P. (2017). Creative writing activities and TPR plus: An implementation of foreign language development project to students with dyslexia. Multilingual Academic Journal of Education and Social Sciences, 2(1), 67-95. https://doi.org/10.6007/majess/v2-i1/1019 
INTERNATIONAL JOURNAL OF ACADEMIC RESEARCH IN BUSINESS AND SOCIAL SCIENCES

Vol. 9, No. 1, Jan, 2019, E-ISSN: 2222-6990 @ 2019 HRMARS

Ko, M. H., \& Goranson, J. (2014). Technology-assisted vocabulary learning and student learning outcomes: A case study. Mulitimedia-Assisted Language Learning, 17(1), 11-33. Retrieved from http://journal.kamall.or.kr/wp-content/uploads/2014/04/Ko+Goranson_17_1_01.pdf

Malcom, H. (2009). How can $20^{\text {th }}$ century classrooms be modified to accommodate the needs $21^{\text {st }}$ century learners? Primary Principals' Sabbatical Report. Waiphili School, New Zealand.

Mustapa, N. , Awang, M., \& Ahmad, A. R. (2016). $21^{\text {st }}$ century knowledge and skills in teaching and learning history. International Conference on Education and Regional Development, Indonesia.

Nordin, A. B. (2013). Kurikulum ke arah penghasilan kemahiran berfikiran kritis, kreatif dan inovatif. Jurnal Kurikulum \& Pengajaran Asia Pasifik, 1(1), 10-18. Retrieved from https://umexpert.um.edu.my/file/publication/00010257_92103.pdf

Ohler, J. (2009). Orchestrating the media collage. Educational Leadership, 66(6), 8-13.

Oxford, R. L., Ehrman, M. E., \& Lavine, R. Z. (1991). Style Wars: Teacher-Student Style Conflicts in the Language Classroom. In S.S, Magnan (Ed.). Challenges for the 1990's for College Language Programs. Boston: Heinle and Heinle / Thomson International.

Redecker, C., Al-Mutka, K., Bacigalupo, M., Ferrari, A. \& Punie, Y. (2009). Learning 2.0: The Impact of Web 2.0 Innovations on Education and Training in Europe. Retrieved from http://publications.jrc.ec.europa.eu/repository/bitstream/JRC55629/jrc55629.pdf

Salkind, N. J. (2010). Pretest-posttest design. In Encyclopedia of research design. http://dx.doi.org/10.4135/9781412961288.n331

Smith, L. H., \& Renzulli, J. S. (1982). Learning style preferences: A practical approach for classroom teachers. Theory Into Practice, 23(1), 44-50. DOI: 10.1080/00405848409543088

Taherdoost, H. (2016). Sampling methods in research methodology; How to choose a sampling technique for research. International Journal of Academic Research in Management, 5(2), 18-27. DOI: $10.2139 /$ ssrn.3205035

Viera, R. T. (2016). Vocabulary knowledge in the production of written texts: A case study on EFL language learners. Revista Tecnologica ESPOL, 30(3), 89-105.

Wallace, B., \& Oxford, R. L. (1992). Disparity in learning styles and teaching styles in the ESL classroom: Does this mean war?. AMTESOL Jorunal, (1), 45-68.

Yamat, H., Fisher, R., \& Rich, S. (2014). Revisiting English language learning among Malaysian children. Asian Social Science, 10(3), 174-180. DOI: 10.5539/ass.v10n3p174

Yunus, M. M., \& Suliman, A. (2014). Information \& communication technology (ICT) tools in teaching and learning literature component in Malaysian secondary schools. Asian Social Science, 10(7), 136-152. DOI: 10.5539/ass.v10n7p136

Yunus, M. M, Lubis, M. A., \& Chua, P.L. (2009). Language learning via ICT: Uses, challenges and issues. WSEAS Transactions on Information Science and Applications, 6(9), 1453-1467. 